


\section{ax $R+1$
$L I B R A R$ untresis of \\ cuiromite}

aAnTा

SCIENC?

LKBAX: 


\section{$+$}

is

$a^{4}$

why



tom

मt

(4) 140

and

and

का की की

and

and

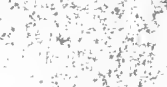

$$
\begin{aligned}
& \text { of } \\
& y^{2} \\
& \text { Hol } \therefore
\end{aligned}
$$


Preliminary Report of the State Earthquake Investigation Commission 


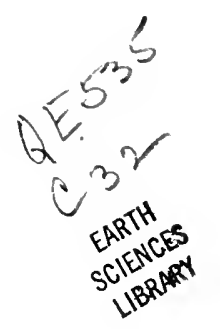

arde 


\title{
PRELIMINARY REPORT OF THE STATE EARTHQUAKE INVESTIGATION COMMISSION.
}

Berkeley, May 31, 1906.

\author{
To His Excellency George C. Pardee, \\ Governor of California.
}

\section{SIR :-}

In response to many inquiries that have been addressed to the State Earthquake Investigation Commission for information coneerning the earthqualie which affeeted a large part of the State of California on April 18, of the eurrent year, your Commission begs to submit a preliminary report of its work and of some of the more salient facts that have eome to light in the course of its labors.

The Commission is aeting under the authority of your letter of April 21, 1906, which reads as follows:-

"To Whom It May Concern:

"The bearer, Professor A. C. Lawson, of the State University, together with Professor G. K. Gilbert of the United States Geologieal Survey, Professor Fielding Reid of Johns Ilopkins University, Professor J. C. Branner of Stanford University, Professor A. O. Leusehner of the State University, Professor George Davidson of the State University, Professor Charles Burkhalter of the Chabot Observatory, and Professor William Wallace Campbell, Direetor of the Liek Observatory, are hereby constituted a Committee of Inquiry into the earthquake phenomena in all parts of the State of California, and the eitizens of the State are hereby requested to eoöperate with this eommittee in all possible ways, affording them all necessary information and aceess to the results of the earthquake disturbances.

$$
\begin{aligned}
& \text { " (Signed) GEo. C. PARdEE, } \\
& \text { "Governor of Calitornia. }
\end{aligned}
$$

“Dated Oakland, Cal., April 21, 1906."

\section{8}


: The Cómmission met for purposes of organization on April sity of California. Professor Andrew C. Lawson was elected Chairman, and Professor A. O. Leuschner Secretary. For purposes of correspondence it was decided that the Commission should be known as the "State Earthquake Investigation Commission." It was determined that the scope of the work of the Commission in its preliminary stages should embrace the questions as to the origin, the position, and the character of the disturbance in the earth's crust which gave rise to the earthquake, these questions to be investigated by :-

1. The location of fault scarps and other deformations of the surface of the ground or sea-bottom in the region affected;

2. The collection of time records leading to the construction of coseismal curves ;

3. The collection of intensity records and their classification in a graded scale leading to the construction of isoseismal eurves.

It was agreed that the intensity should be considered in its relation to geological formations and structures, and in its relation to man; that the relationship between types of manifestation and the characters of transmitting formations should be studied with the object of determining the cause of relative immunity of certain localities and of violent destruetion in others; that in the interpretation of intensity from the destruction of buildings, etc., the character of the structure should be carefully considered.

Having outlined the scope of its work, the Commission appointed two committees, one on isoseismals, Andrew C. Lawson Chairman, and one on coseismals, A. O. Leuschner Chairman. The chairman of each committee was authorized to name the members of his committee, the membership of the committee not being confined to the Commission. The Commission by vote invited the coöperation of the San Francisco Branch of the American Association of Civil Engineers by asking them to make available to the Commission any data they might collect or results or conclusions they might reach; a similar service to be rendered to the Association by the Commission.

In view of the alarming reports which were in circulation after the earthquake, the Commission authorized the issuance by 
the press of a statement to the effeet that the times of earthquakes eannot be predieted, and that any predictions such as had been eurrent were unwarranted; that severe earthquakes are generally followed by a number of minor shocks extending over several days, or even weeks; and that the physiographic conditions of the bay region are such as to preelude any serious damage from sea waves, popularly ealled the "tidal waves," due to earthquake disturbanees.

The Commission then formulated a eireular, and ordered its issue to the press of California, requesting the people of the State to eöoperate with it in the eollection of data. The eireular appears as Appendix $A$ to this report.

Professor Lawson named as the Committee on Isoseismals: G. K. Gilbert, J. C. Branner, A. S. Eakle, H. O. Wood, R. S. Holway, F. E. Matthes, C. E. Weaver, J. N. LeConte, H. W Fairbanks, G. D. Louderbaek, J. A. Reid, E. S. Larsen, F. J. Rogers, and J. F. Newsom.

Professor Leuschner named as the Committee on Coseismals: H. F. Reid, W. W. Campbell, George Davidson, Alexander MeAdie, Charles Burkhalter, R. T. Craw'ord, Burt L. Newkirk, A. J. Champreux, S. D. Townley, and J. N. LeConte.

At a subsequent meeting of the Commission it was deeided to establish a third eommittee on the geophysies of the earthquake, and the Chairman was authorized to appoint such a eommittee. He named Professor Harry Fielding Reid (Chairman), L. M. Hoskins, and C. F. Marvin as the eommittee. Dr. F. Omori, Professor of Seismology in the Imperial University of Tokyo, and Professor Nakamura, also of Tokyo, were eleeted associate members of the Commission.

Immediately after the earthquake and before the appointment of the Commission, the seientific men of the State had been active in the investigation of the effeets of the earthquake, and the appointment of the Commission and the plan of work which it formulated served to organize their efforts and bring the results of their observations together. From the purely seientifie point of view, the earthquake of the 18th of April is one of the most interesting on record, and in some respeets it is unique. A complete study of the phenomena will undoubtedly eontribute 
greatly not only to our knowledge of the evolution of the earth's crust, but also to our knowledge of the means of minimizing the calamities which arise from the destruction of buildings, water pipes and other structures, when such shocks occur in the future. Certain of the studies which have this important object in view fall within the province of the structural engineer and the architect, and they have already formulated many suggestions dealing with principles and materials of construction which will be of very great value in the future construction of buildings, not only in San Francisco but in all parts of the country which are subject to earthquake shocks. Other studies having the same beneficent object in view are more properly germain to the purposes of your Commission. These refer ohiefly to the relation between destructive effects and the character of the ground and underlying rocks upon which structures stand; and to this question your Commission has given especial attention. It has also had constantly in mind the desirability of discovering evidence upon which a judgment might be based as to the probability of recurrence of the earthquake in the future.

Having thus far outlined the organization of the Commission, its more important official acts, and the scope and plan of its work, a word may be said regarding the methods employed before going on to a statement of the general results attained, and of the problems which remain as yet to be solved. The Committee on Coseismals, being concerned with the records of the times at which the earthquake was felt, has thus far had to depend largely upon correspondence for its information. The records are of two kinds : first those which are based upon personal observations at the time of the shock, and secondly those which were automatically registered by delicate instruments not only in different parts of the State but also throughout the civilized world. For the latter the Committee is under obligations to seismologists in many lands as well as our awn. For the purpose of collecting the time records in possession of the citizens of the State based upon their personal observation, the Committee on Coseismals issued a supplementary circular, a copy of which is hereto appended as Appendix B. In securing replies to the questions set forth in this circular from people in the territory affected who 
had special opportunities for observing the time of the earthquake accurately, the Committee on Coseismals was fortunate in being able to avail itself of the hearty coöperation and assistance of various branches of the public service and of the several railroad, telegraph, and telephone companies operating in the State, through their exeeutive officers. Such aid has been notably rendered by the officers of the United States Weather Bureau, the United States Coast and Geodetic Survey, the United States Lighthouse Service, and several offieers of the United States Army, and of the Navy. The agents and operators of the Southern Pacific Railway, the Atchison, Topeka and Santa Fé Railway, the California Northwestern Railway, the Western Union Telegraph Company, the Postal Telegraph Company, and the Pacific States Telephone and Telegraph Company, and many teachers in the high schools of the State have all been enlisted in the work of supplying the observed times of the shock in various parts of the State.

The Committee on Isoseismals has also been greatly assisted by information contributed by citizens of the State in response to inquiries sent out through the press. The numerous replies that have been received indicate a very widespread and intelligent interest in the phenomena in its purely scientifie aspects. But the more important collection of data by this Committee has been and is being made by field observation by members of the Committee and their aides.

\section{RESULTS.}

One of the remarkable features of the Coast Ranges of California is a line of peculiar geomorphic expression which extends obliquely across the entire width of the mountainous belt from Mendoeino County to Riverside County. The peculiarity of the surface features along this line lies in the fact that they are not due, as nearly all the other features of the mountains are, to atmospheric and stream erosion of the uplifted mass which constitutes the mountains, but have been formed by a dislocation of the earth's crust, or rather a series of such dislocations, in time past, with a differential movement of the parts on either side of the plane of rupture. In general this line follows a system of 
long narrow valleys, or where it passes through wide valleys it lies close to the base of the confining hills, and these have a very straight trend; in some places, however, it passes over mountain ridges, usually, at the divide separating the ends of two valleys; it even in some cases goes over a spur or shoulder of a mountain. Along this line are very commonly found abrupt changes in the normal slope of the valley sides giving rise to what are technically known as scarps. These scarps have the appearance of low precipitous walls which have been usually softened and rounded somewhat by the action of the weather. Small basins or ponds, many laving no outlct, and some containing saline water, are of fairly frequent occurrence and they usually lie at the base of the small scarps. Trough-like depressions also oceur bounded on both sides by scarps. These troughs and basins can only be explained as due to an actual subsidence of the ground, or to an uplift of the ground on one side or the other, or on both sides. The scarps similarly can only be ascribed to a rupture of the earth with a relative vertical displacement along the rupture plane. Frequently small knolls or sharp little ridges are found to characterize this line and these are bounded on one side by a softened scarp and separated from the normal slope of the valley side by a line of depression. In many cases these features have been so modified and toned down by atmospheric attack that only the expert eye can recognize their abnormal character; but where their line traverses the more desert parts of the Coast Range, as for example in the Carissa Plains, they are well known to the people of the country and the aggregate of the features is commonly referred to as the "earthquake crack."

This line begins on the north at the mouth of Alder Creek near Point Arena and extends southeasterly nearly parallel with the coast line to a point about two miles below Fort Ross, a distance of forty-three miles. Here it passes outside of the shore line and is again met with at the point where Bodega Head joins the mainland. Thence it appears to continue southward through Tomales Bay and Bolinas Lagoon. Beyond Bolinas Lagoon it passes outside of the Golden Gate and enters the shore again at Mussel Rock, eight miles south of the Cliff House. From this point it is traceable continuously along the valley line occupied 
by San Andreas and Crystal Springs Iakes, past Woodside and Portola, over a saddle baek of Blaek Mountain, thence along Stevens Creek Cañon, passing to the southwest of Table Mountain and Congress Springs to the vicinity of Wrights, on the narrow-gauge railway between San José and Santa Cruz. From Wrights it eontinues on in the same course through the Santa Cruz Mountains to the point where the Southern Pacifie Railway crosses the Pajaro River near Chittenden. From the erossing of the Pajaro the line extends up the valley of the San Benito River, aeross the eastern portion of Monterey County, and thenee follows the northeastern side of the valley of the San Juan River and the Carissa Plains to the vieinity of Monnt Pinos, in Ventura County. The line thus traeed from Point Arena to Mount Pinos has a length of 375 miles, is remarkably straight, and euts obliquely aeross the entire breadth of the Coast Ranges. To the south of Mount Pinos the line either bends to the eastward following the general eurvature of the ranges or is paralleled by a similar line offset from it en echelon; for similar features are reported at the Tejon Pass and traeeable thenee though less eontinuously aeross the Mojave Desert to Cajon Pass and beyond this to San Jacinto and the southeast border of the Colorado Desert. The probability is that there are two sueh lines, and that the main line traced from Point Arena to Mount Pinos is eontinued with the same general straight trend past San Fernando and along the base of the remarkably even fault searp at the foot of which lies Lake Elsinore. But, leaving the southern extension of the line out of eonsideration as somewhat debatable, we have a very remarkable physiographic line extending from Point Arena to Mount Pinos which affords every evidenee of having been in past time a rift, or line of disloeation, of the earth's erust and of recurrent differential movement along the plane of rupture. The movements whieh have taken place along this line extend far baek into the Quaternary period, as indieated by the major, well degraded fault searps and their assoeiated valleys; but they have also oceurred in quite reeent times, as is indieated by the minor and still undegraded scarps. Probably every movement on this line produced an earthquake, the severity of which was proportionate to the amount of movement. 
The cause of these movements in general terms is that stresses are generated in the earth's crust which accumulate till they exceed the strength of the rocks composing the crust and they find a relief in a sudden rupture. This establishes the plane of dislocation in the first instance, and in future movements the stresses have only to accumulate to the point of overcoming the friction on that plane and any cementation that may have been effected in the intervals between movements.

The earthquake of the 18th of April, 1906, was due to one of these movements. The extent of the rift upon which the movement of that date took place is at the time of writing not fully known. It is, however, known from direct field observations that it extends certainly from the mouth of Alder Creek near Point Arena to the vicinity of San Juan in San Benito County, a distance of about 185 miles. The destruction at Petrolia and Ferndale in Humboldt County indicates that the movement on the rift extended at least as far as Cape Mendocino, though whether the line of rift lies inland or off shore in that region is still a matter of inquiry. Adding the inferred extension of the movement to its observed extent gives us a total length of about three hundred miles. The general trend of this line is about N. $35^{\circ}$ W., but in Sonoma and Mendocino counties it appears to have a slight concavity to the northeast, and if this curvature be maintained in its path beneath the waters of the Pacific it would pass very close to and possibly inside of Capes Gordo and Mendocino. Along the 185 miles of this rift where movement has actually been observed the displacement has been chiefly horizontal on a nearly vertical plane, and the country to the southwest of the rift has moved northwesterly relatively to the country on the northeast of the rift. By this it is not intended to imply that the northeast side was passive and the southwest side active in the movement. Most probably the two sides moved in opposite directions. The evidence of the rupture and of the differential movement along the line of rift is very clear and unequivocal. The surface soil presents a continuous furrow generally several feet wide with transverse cracks which show very plainly the effort of tortion within the zone of the movement. All fences, roads, stream courses, pipe lines, dams, conduits, and property 
lines which cross the rift are dislocated. The amount of disloeation varies. In several instances observed it does not exceed six feet. A more common measurement is eight to ten feet. In some eases as much as fifteen or sixteen feet of horizontal displacement has been observed, while in one case a roadway was found to have been differentially moved twenty feet. Probably the mean value for the amount of horizontal displacement along the rift line is about ten feet and the variations from this are due to local causes such as drag of the mantle of soil upon the roclis, or the excessive movement of soft incoherent deposits. Besides this general horizontal displacement of about ten feet there is observable in Sonoma and Mendocino counties a differential vertical movement not exceeding four feet, so far as at present known, whereby the southwest side of the rift was raised relatively to the northeast side, so as to present a low scarp facing the northeast. This vertical movement diminishes to the southeast along the rift line and in San Mateo County is searcely if at all observable. . Still farther south there are suggestions that this movement may have been in the reverse direction, but this needs further field study.

As a consequence of the movement it is probable that the latitudes and longitudes of all points in the Coast Ranges have been permanently changed a few feet, and that the stations occupied by the Coast and Geodetic Survey in their triangulation work have been changed in position. It is hoped that a reoccupation of some of these stations by the Coast and Geodetic Survey may contribute data to the final estimate of the amount of movement.

The great length of the rift upon which movement has oceurred makes this earthquake unique. Such length implies great depth of rupture, and the study of the question of depth will, it is believed, contribute much to eurrent geophysical conceptions.

The time of the beginning of the earthquake as recorded in the Observatory at Berkeley was $5^{\mathrm{h}} 12^{\mathrm{m}} 6^{\mathrm{s}}$ a.m., Pacific standard time. The end of the shock was $5^{\mathrm{h}} 13^{\mathrm{m}} 11^{\mathrm{s}}$ a.m., the duration being $1^{\mathrm{m}} 5^{\mathrm{s}}$. Within an hour of the main shock twelve minor shocks were observed by Mr. S. Albrecht of the Observatory and their time accurately noted. Before $6^{\mathrm{h}} 52^{\mathrm{m}}$ p.m. of the same 
day thirty-one shocks were noted in addition to the main disturbance. These minor shocks continued for many days after April 18, and in this respect the earthquake accords in behavior with other notable earthquakes in the past. The minor shocks which succeed the main one are interpreted generally as due to subordinate adjustments of the earth's crust in the tendency to reach equilibrium after the chief movement.

The collection of time records necessarily proceeds slowly. The purpose of the coseismal curves based upon these records is in general two-fold. In ordinary earthquakes it is one of the means of locating the seat of the disturbance when there is no surface manifestation of the rupture in the earth's crust. In the present instance, however, the rupture has declared itself in an unmistakable rift observable at the surface, and coseismals are therefore unnecessary for the determination of this important factor in the general problem, so far at least as regards the main disturbance. It is probable, however, that so radical a change in the equilibrium of the stresses of the earth's crust would induce secondary ruptures and consequently secondary earthquakes closely associated with the chief shock. The careful plotting of the time records may, therefore, be useful in revealing the location of these secondary disturbances, such for example as the one which affected Southern California on the afternoon of the 18th of April. The second purpose of securing time records is the determination of the velocity of propagation of the earth wave; and the data for this which are likely to be most serviceable are the records obtained at various quite distant seismographic stations.

The destructive effects of the earthquake are in the main distributed with reference to the line of rift. The exact limits of the area of destruction have not yet been mapped, but it is known to extend out about twenty-five or possibly thirty miles on either side of the rift. On the southwest side the greater part of this area to the north of the Golden Gate lies in the Pacific. This area extends from Eureka in Humboldt County to the southern extremity of Fresno County, a distance of about four hundred miles.

Beyond this area of destructive shock the earthquake was felt 
in its milder manifestations over a wide territory. Our reports to date show that it was felt in Oregon as far north as Coos Bay and on the south as far as Los Angeles. To the east it was felt over the greater part of middle California and eastern Nevada, partieularly along the eastern flank of the Sierra Nevada. It was felt at Loveloeks, and we have uneonfirmed reports of its having been felt at Winnemueca. Far beyond the region within whieh it was apparent to the senses, however, the earth wave was propagated both through the earth and around its periphery; and some of the most valuable and most aeeurate reeords of the disturbance which we have are those whieh were registered at sueh distant seismographie stations as Washington, D. C. ; Sitka, Alaska ; Potsdam, Germany ; and Tokyo, Japan.

Within the area of destruetive effeets approximately 400 by 50 miles in extent the intensity varied greatly. There was a maximum immediately on the rift line. Water pipes, eonduits, and bridges erossing this line were rent asunder. Trees were uprooted and thrown to the ground in large numbers. Some trees were snapped off, leaving their stumps standing, and others were split from the roots up. Buildings and other struetures were in general violently thrown and otherwise wreeked, though some eseaped with but slight damage. Fissures opened in the earth and elosed again, and in one ease reported a eow was engulfed. A second line of maximum destruetion lies along the floor of the valley system of which the Bay of San Franeiseo is the most notable feature, and partieularly in the Santa Rosa and Santa Clara valleys. Santa Rosa, situated twenty miles from the rift, was the most severely shaken town in the State and suffered the greatest disaster relatively to its population and extent. Healdsburg suffered to a nearly similar degree. San José, situated thirteen miles, and Agnews, about twelve miles from the rift, are next in the order of severity. Stanford University, seven miles from the rift, is probably to be placed in the same eatecrory. All of these plaees are situated on the valley floor and are underlain to a considerable depth by loose or but slightly eoherent geologieal formations, and their position strongly suggests that the earth waves as propagated by such formations are much more destructive than the waves which are propagated by the firmer 
and highly elastic rocks of the adjoining hill lands. This suggestion is supported by a consideration of the destructive effects exhibited by towns and single buildings along the same valley line which are situated wholly or partly on rock. Petaluma and San Rafael, though nearer the rift than Santa Rosa, suffered notably less, and they are for the most part on, or close to, the rocky surface. The portions of Berkeley and Oakland which are situated on the alluvial slope suffered more than the foothills, where the buildings are founded on rock. The same suggestion is further supported from a consideration of the zone of maximum destructive effect on the southwest side of the rift. This zone lies in the Salinas Valley. The intensity of destructive action at Salinas was about the same as at San José, and the town is situated on the flood plain deposits of the Salinas River. Along the banks of the Salinas River and extending from Salinas to the vicinity of Gonzales, so far as our reports at present show, the bottom lands were more severely ruptured, fissureci. and otherwise deformed than in any other portion of the State. The Spreckels Sugar Mill, situated on the banks of the river, suffered more severely probably than any other steel structure in the State. Santa Cruz, on the other hand, which is on the same side of the rift, and at the same distance from it, but which is built on rock for the most part, suffered much less damage. In the northern counties along the coast the most severe effects were felt at Ferndale, on the south margin of the flood plain of the Eel River, and at Petrolia, on the bottom land of the Mattole. Fort Bragg was severely shaken with very destructive effects, but our reports do not yet indicate the character of the ground upon which it is situated.

In the facts which have been cited we seem to have warrant for a generalization as to the excessively destructive effect of the earth wave as transmitted by the little coherent formations of the valley bottoms. But it must be borne in mind that by far the greater number of structures subject to destructive shock are situated in the valley lands and that there has not yet been time for a detailed comparison of the effects in the valleys with those in the hills, where the buildings are founded on firm rock except in a few notable instances. 
The most instructive of these instances is the city of San Francisco, and the facts observed there are entirely in harmony with the generalization above outlined. In the city of San Francisco we may recognize for preliminary purposes four types of ground: (1) The rocky hill slopes; (2) the valleys between the spurs of the hills which have been filled in slowly by natural processes; (3) the sand dunes; (4) the artificially filled land on the fringe of the city. Throughout the city we have a graded scale of intensity of destructive effects which corresponds closely to this classification of the ground. The most violent destruction of buildings, as everybody knows, was on the made ground. This ground seems to have behaved during the earthquake very much in the same way as jelly in a bowl, or as a semi-liquid material in a tank. The earth waves which pass through the highly elastic rocks swiftly with a small amplitude seem in this material to have been transformed into slow undulations of great amplitude which were excessively destructive. The filled in material and the swampy foundation upon which it rests behaved, in other words, as a mass superimposed upon the earth's surface, rather than as a part of the elastic crust itself. In a less degree the same thing is true of the sand dune areas, where the ground was frequently deformed and fissured. In still less degree the naturally filled valleys between the hill spurs were susceptible to this kind of movement, and the destruction of buildings was correspondingly less, but still severe, depending very largely on the character of the buildings, the integrity of their construction, etc. In portions of these valleys, however, the original surface of the ground has been modified by grading and filling, and on the filled areas the destruction was more thorough than elsewhere in the same valley tracts. On the rocky slopes and ridge tops, where, for the most part, the vibration communicated to buildings was that of the elastic underlying rocks, the destruction was at a ninimum. On some of the hills chimneys fell very generally and walls were eracked; on others even the chimneys withstood the shock.

While this correlation of intensity of destructive effect appears to hold as a generalization, there are well known exceptions which find their explanation in the strength of the structures. 
Modern class A steel structures with deep foundations appear to have been relatively passive, while the made ground in their immediate vicinity was profoundly disturbed. Thoroughly bonded and well cemented brick structures, on similarly deep and solid foundations, seem to have been equally competent to withstand the shock, except for occasional pier-like walls not well tied to the rest of the building. The weak points in wooden frame structures were in general the faulty underpinning and lack of bracing, and chimneys entirely unadapted to resist such shocks. With these faults corrected, frame buildings of honest construction would suffer little damage beyond eracking of plaster in such a shock as the 18th of April, save on the made ground, where deep foundations and large mass appear to be essential for the necessary degree of passivity.

Pipe lines and bridges crossing the rift line present a peculiar, if not quite unique, engineering problem which will doubtless be solved in the near future. Pipe lines on low swampy ground or in made ground are in much greater danger of destruction from earthquake shocks than those on high ground underlaid by rock, except in the immediate vicinity of the rift, where nothing could be constructed which would withstand the violence of the earth movement.

One of the lessons of the earthquake which seems peculiarly impressive is the necessity for studying carefully the site of proposed costly public buildings where large numbers of people are likely to be congregated. In so far as possible such sites should be selected on slopes upon which sound rock foundation can be reached. It is probably in large measure due to the fact of their having such a rock foundation that the buildings of the State University, at Berkeley, escaped practically uninjured. 'The construction of such buildings as our public schools demands the most earnest attention of the people and of the authorities charged with their construction. A great many of our schools proved to be of flimsy construction and ill adapted to meet the emergency of an earthquake shock of even less severity than that of the 18th of April.

The Commission in presenting this brief report has had in mind the demand on the part of the people of the State and of 
the world at large for reliable information as to the essential facts of the earthquake. It has, therefore, not presumed to engage in any diseussion of the more abstruse geological questions which the event naturally raises. It leaves such discussion for a more exhaustive report which can only be prepared after the campaign of data eollection is complete, and that may be some months hence.

Very respectfully submitted in behalf of the Commission,

Andrew C. Lawson,

Chairman.

A. O. Leuschner,

Secretary. 


\section{APPENDIX A.}

\section{STATE EARTHQUAKE COMMISSION, BERKELEY, CALIFORNIA, APRIL 25, 1906.}

It is of importance that the citizens of the State of California coöperate with the State Earthquake Commission in its investigation of the recent seismic disturbance. For this purpose it is essential that the Commission receive as soon as possible information on any or all of the topics outlined below. All communications should be addressed to the State Earthquake Coumission, University of California, Berkeley, California.

Give information on the following:

1.--Post-office address; town, county, and state.

2.-Place and date of observation.

3.-Name and address of the observer, if other than the writer.

4.-Give estimate of the intensity of the earthquake on the Rossi-Forel Scale. The Rossi-Forel Scale as amended by the Commsssion is as follows:

I. Perceptible, only by delicate instruments.

II. Very slight, shocks noticed by few persons at rest.

III. Slight shock, of which duration and direction was noted by a number of persons.

IV. Moderate shock, reported by persons in motion; shaking of movable objects; cracking of ceilings.

V. Smart shock, generally felt; furniture shaken; some clocks stopped; some sleepers awakened.

VI. Severe shock, general awakening of sleepers; stopping of clocks; some window glass broken.

VII. Violent shock, overturning of loose objects; falling of plaster; striking of church bells; some chimneys fall.

VIII. Fall of chimneys; cracks in the walls of buildings.

IX. Partial or total destruction of some buildings.

$X$. Great disasters; overturning of rocks; fissures in the surface of the earth; mountain slides.

5.-Give any facts that you can as to the directions the Earthquake Waves seemed to travel. Describe the character of the shock, whether a temblor or an oscillatory motion, etc., and whether you, yourself, or others had any clear impressions as to the direction in which it was moving, the facts on which this impression was based and whether people agreed as to the direction.

6.-Give also any further particulars of interest, whether they are from observation or hearsay. If any changes occurred in the ground, such as depressions or elevations of the surface, fissures, emissions of sand or water, describe them fully. Character of damage to buildings. General direction in which walls, chimneys and columns in cemeteries were overthrown. Springs, wells, and rivers are often notably affected, even by slight shocks, and any information in regard to such changes will be valuable. 
7.- - State as exactly as possible the time of commenememt and the duration of "ach shork.

'The exalet time of the begimning of a shock (to the nespest sexeond), one of the most important of all ohservations, is diffienlt to get correetly, beeamse of the great velocity with which the wave travels, and beeanse the watch or eloek must he immediately compared with a eloek known to be kepping standard time. If several hours have elapsed hefore the eomparison is made, another comparison should be made an hour later, in order to find whether your timepipee is galining or losing. The observation cannot be regarded as a good one, unless it is stated that this has been done. Telegraph operators, railroad officials, watehmakers, ete., have espeeially good olportunities for answering this question corpectly, and their coopreration is most earnestly solieited.

If a cloek was stopped, give the exaet time it indieated (and anything known, as how fast or how slow it was), its position, the direction in whieh it was faeing, and the length of the pendulum.

8.- - If a shoek was not felt in your neighborhood, althongh noticed at places not very far distant, do not fail to answer the first four questions, as negative reports are of great interest in defining the limits of the. disturbed area, ete. State also the nearest point to your station where the shock was felt.

9.-Name of the writer.

NOTE.-In replying to these questions, they need not be repeated; but the answers should be numbered to correspond to the questions.

APPENDIX B.

\section{COSEISMALS.}

QUESTIONS REGARDING THE EARTHQUAKE SHOCKS ON AND AF'TER APRIE, 18, 1906.

Date of shock.

1. Town. County, State

?. Observer

3. Ohserver's address and orupation

4. Situation and oceupation of the observer at the time 
Record for each shock in separate column.

5. Time, direction, etc.-

A. Time of commencement

B. Duration

( $\therefore$. Direction of shock

(a) Vertical

(b) Horizontal

(e) Direction in which objects were overturned

(d) Apparent direction of propagation

D. Seconds of tremulous motion-

(a) Before

(b) After

F. Nature of shock-

(a) Did intensity gradually increase and then die away?

(b) Were there two or more maxima of intensity? If so, what was the interval between them and the oriler of their intensity?

(c) Was the principal disturbance strongest near the beginning, the midlle, or the end of the series? ....

F. Atopping of clocks-

(a) Time

(b) Equivalent length of pendulum

(c) Clock faced

G. Sound phenomena-

(a) Was any unusual rumbling sound heard at the time of the shock, and, if so, what did it resemble? ....

(b) Did the beginning of the sound precede, coincide with, or follow the beginning of the shock, and by how many seconds?

A $\quad B \quad C \quad$ D $\quad E \quad F$

a) Did the end of the sound precede, coincide with, or follow the end of the shock, and by how many seconils?

(d) Did the sound become gradually louder and then die away?

(c) Dirl the instant when the sound was loudest precerle, coincide with, or follow the instant when the disturbance was strongest, and by how many seconds?

(f) Did the sound change in character at or about the time when the disturbance was strongest?

Recorder

Return to State Earthquake Commission, Berkeley, Cal. 

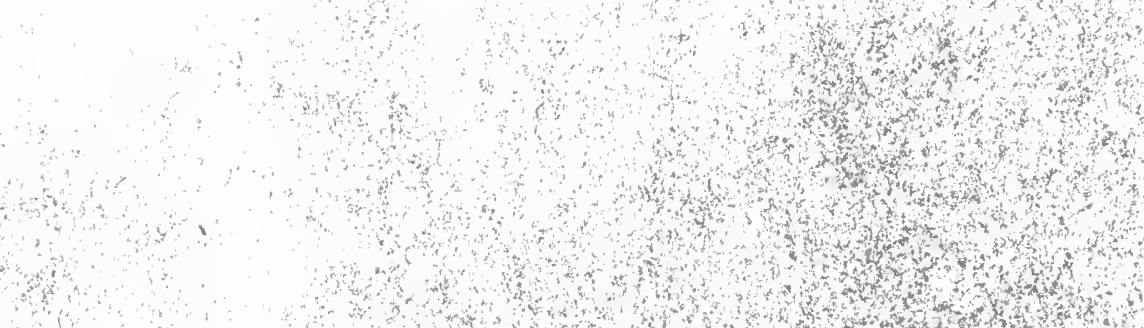

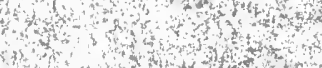

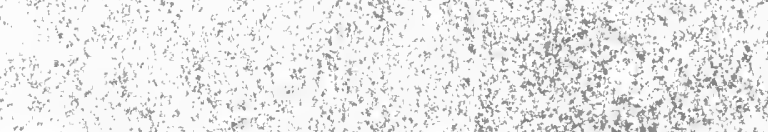

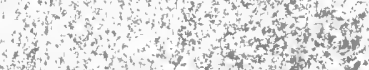

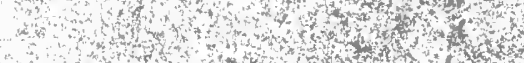

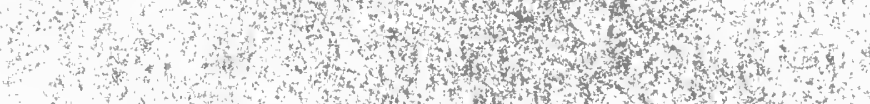

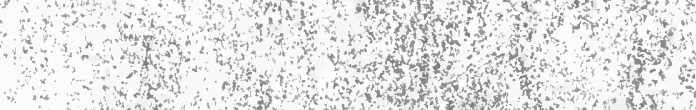

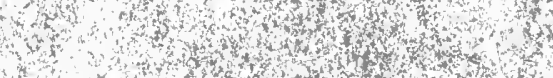

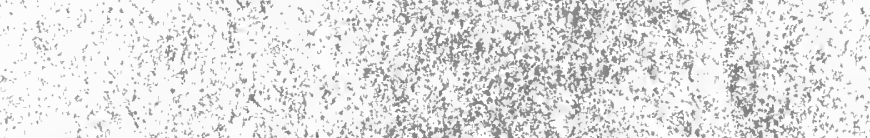



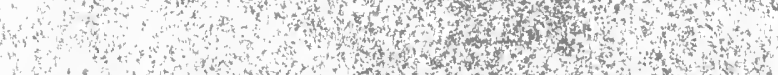

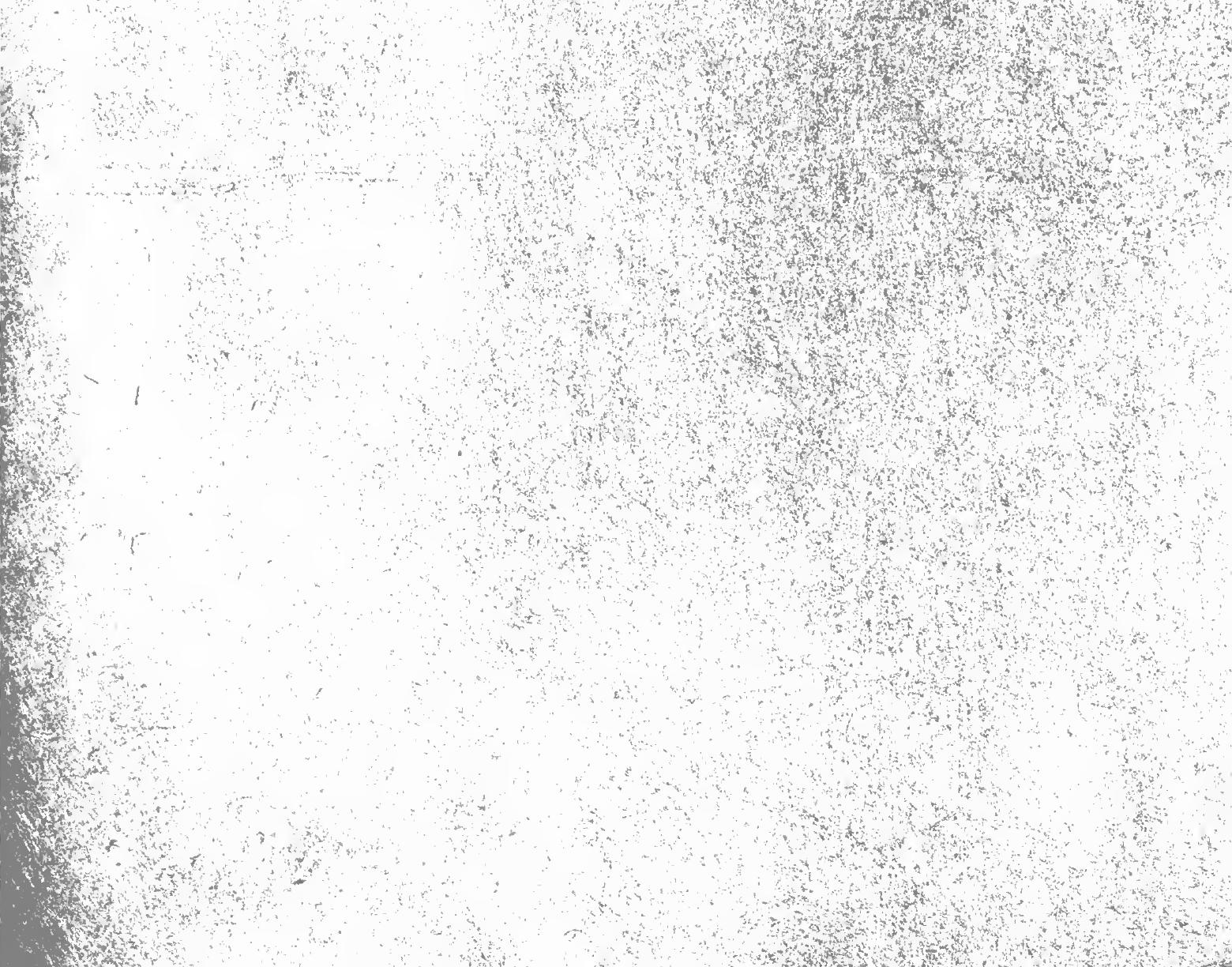


14 DAY USE

RETURN TO DESK FROM WHICH BORROWED

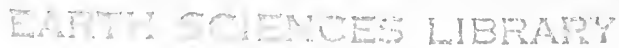

This book is due on the last date stamped below, or on the date to which renewed.

Renewed books are subject to immediate recall.

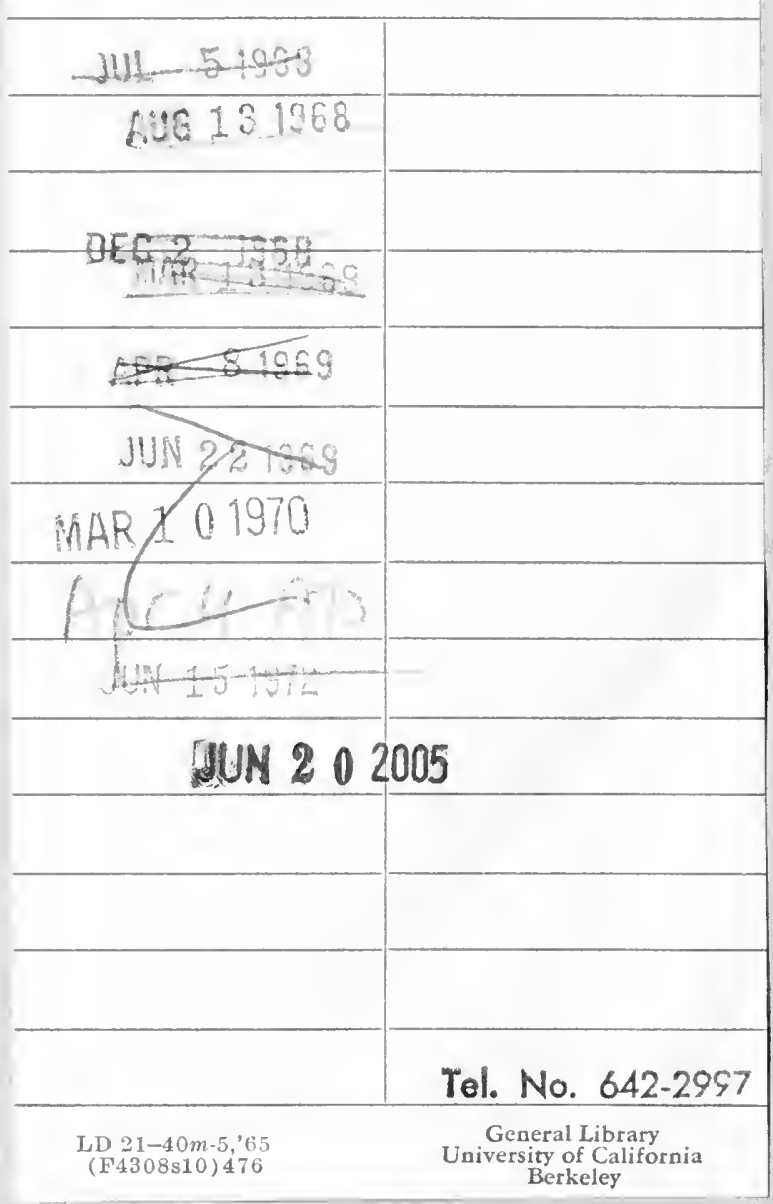


638

storage 




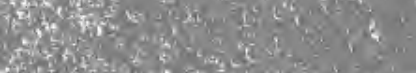

tag

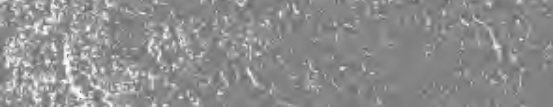

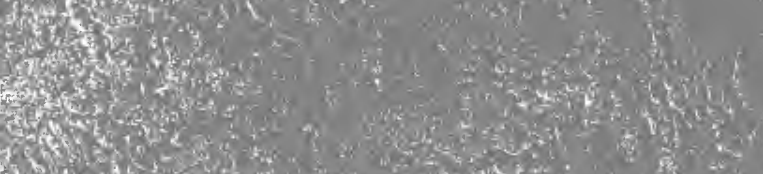

20.

20.

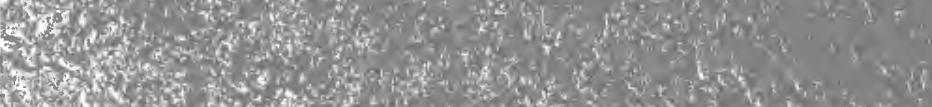

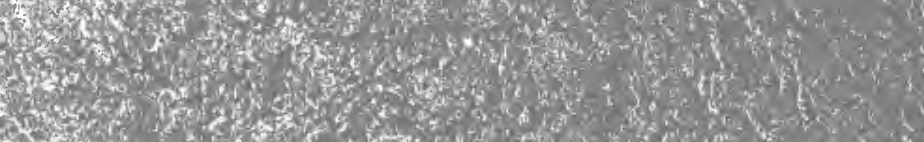

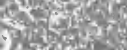

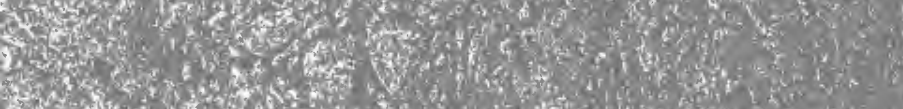

(3)

3.

20)

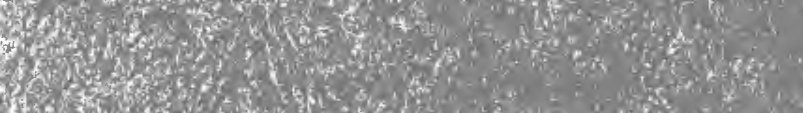

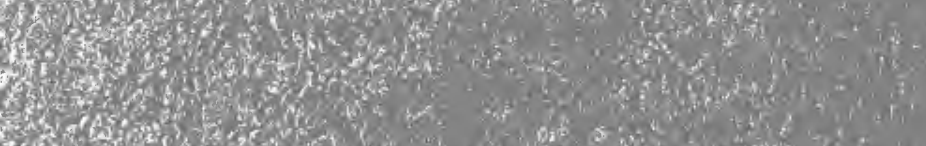

